\section{Re: 24-Hour Urinary Calcium in Primary Hyperparathyroidism; Black et al.}

Editor - I read with interest the very interesting paper by Black et $\mathrm{al}^{1}$ delineating the relationship between 24-hour urine calcium and several variables. My first observation is that the relationship of 24-hour urine calcium to either 24-hour urine creatinine or age may have been confounded by incompleteness of the collection. The normal rate of creatinine excretion (which is equal to creatinine production in the steady state) in adults under the age of 50 is about 20 to 25 $\mathrm{mg} / \mathrm{kg}$ (177 to $221 \mathrm{micromol} / \mathrm{kg}$ ) of lean body weight in men and 15 to $20 \mathrm{mg} / \mathrm{kg}$ (133 to $177 \mathrm{micromol} / \mathrm{kg}$ ) of lean body weight in women ${ }^{2,3}$. From the ages of 50 to 90 , there is a progressive 50 percent decline in creatinine excretion (to about $10 \mathrm{mg} / \mathrm{kg}$ in men), due primarily to a fall in muscle mass. This data can be used to decide on the completeness or otherwise of the collection based on published guidelines such as the ratio of urinary creatinine ( $\mathrm{mg} /$ day) and body weight $(\mathrm{kg})$ of $<10.8$ or $>25.2$ as suggested by the $\mathrm{WHO}^{4}$. These relationships then need to be adjusted for the latter variable to ensure that these are simply not spurious because of varying levels of completeness of collection across these subjects.

Secondly, I suspect that the Vitamin D relationship with the 24-hour urine calcium is an inverse relationship such that a low Vitamin D predisposes to a lower 24-hour urine calcium and this is suggested by the results in Black's ${ }^{1}$ Table 2 . The results in Table 3 may be non-significant simply because the threshold for 24-hour urine calcium has been set too high such that subjects with values $<400 \mathrm{mg}$ /day can be both Vitamin D deficient and sufficient. In order to elucidate this, can the authors provide an ROC analysis with two cutoffs of Vitamin D as the criterion (deficient $<30 \mathrm{nmol} / \mathrm{L}(12 \mathrm{ng} / \mathrm{ml})$ and insufficient $<50 \mathrm{nmol} / \mathrm{L}(20 \mathrm{ng} / \mathrm{ml}))$ and advise what the area under curves are as well as what the optimal cutoff points are for 24-hour urine calcium if the latter are indeed significant?

\section{References}

1. Black CE, Berg RL, Urquhart AC. 24-hour urinary calcium in primary hyperparathyroidism. Clin Med Res 2013;11: 219-225.

2. Walser M. Creatinine excretion as a measure of protein nutrition in adults of varying age. JPEN J Parenter Enteral Nutr 1987;11:73S-78S.

3. Ix JH, Wassel CL, Stevens LA, Beck GJ, Froissart M, Navis G, Rodby R, Torres VE, Zhang YL, Greene T, Levey AS. Equations to estimate creatinine excretion rate: the CKD epidemiology collaboration. Clin J Am Soc Nephrol 2011;6:184-191.

4. Murakami K, Sasaki S, Takahashi Y, Uenishi K, Watanabe T, Kohri T, Yamasaki M, Watanabe R, Baba K, Shibata K, Takahashi T, Hayabuchi H, Ohki K, Suzuki J. Sensitivity and specificity of published strategies using urinary creatinine to identify incomplete 24-h urine collection. Nutrition 2008;24:16-22.
Suhail A.R. Doi

School of Population Health

University of Queensland

Brisbane

Australia

Email:sardoi@gmx.net

Received: March 19, 2014

Accepted: March 25, 2014

doi: $10.3121 / \mathrm{cmr} .2014 .1240$ 